\title{
Career Development in the Uniformed Services of Lithuania: Wide Open Innovation Possibilities vs. Innert Hierarchical Culture
}

\author{
Svajūnė Ungurytė-Ragauskienė, Mantas Bileišis \\ Mykolas Romeris University \\ Didlaukio str. 55. LT-08303 Vilnius \\ cross $^{\text {ref }}$ http://dx.doi.org/10.5755/j01.ppaa.16.3.19335
}

\begin{abstract}
We compare career development models between two uniformed services regimes of Lithuania: military and statutory (police and penitentiary services). In this paper, we differentiate regulative and normative institutions by comparing the egzisting regulation that relates to career development and interview accounts of servicemembers regarding their understanding of career development paths and institutional factors that affect them. We find that regulations between the two regimes are similar; however, there are radical differences in how service members perceive career development. We conclude that other, non-regulatory, factors are at play: (i) considerable legacies of in statutory services since the Sovietera, and (ii) the exposure of the military service to international practices in the context of NATO alliance. Statutory services inherited their personnel, organizational structure and, to some extent, regulations from the Soviet-era, whereas the military was built from scratch, largely based on conditionalities set by NATO accession. Although we see striking similarities in human resource management (HRM) regulations among services regimes, there are no comparable similarities with regard to how service members view career development. Career development is not regulated in detail in either service regime and serves as a good indicator of normative institutions that shape uniformed services. Service member accounts lead us to conclude that elements of career development that are applied in the military service achieves better HRM outcomes.
\end{abstract}

Keywords: career development, military service, statutory service, public service regimes, uniformed services, Lithuania.

Raktažodžiai: karjeros vystymas, karo tarnyba, statutine tarnyba, viešosios tarnybos režimai, Lietuva. 


\section{Introduction}

Since 1990, the Lithuanian system of public service has undergone considerable change. Nonetheless, this change has not been as revolutionary as one may imagine. The Soviet Union despite its totalitarian methods of governance did maintain extensive administrative structures at the level of so-called national republics, one of which was Lithuania. This administration was mostly ethnicly Lithuanian and independent Lithuania remained within the geographic scope of its soviet predecessor, which meant that many of them lingered on beyond 1990. In the period of 1990-1995 few reforms of administration of civil service took place [11]. In this regard, Lithuania is the odd case out in the context of the Baltic States [3]. Nearly all elements of administrative reform in Lithuanian happened and continue to happen incrementally, with the few more radical reform initiatives failing to gain much ground. In this respect, Soviet legacy needs to be seen as a factor shaping processes, staffing and regulation of public organizations. This context, however, does not apply across the board. Lithuania needed to build its military and diplomatic services from scratch with no legacy structures to fall back on.

In recent years, in the wake of 2014 Russian annexation of Crimea Lithuanian policymakers have drawn their attention towards strengthening the uniformed services. Primarily, this concerns investments in defense. However, other uniformed services have attracted attention of policymakers as well. The reforms that are now being roled out require attracting qualified staff, and that is proving difficult. As a result, career development and other human resource management (HRM) tools have been finding their way to these services. Different services have gone about differently in tackling their human resource (HR) challenges. In this article, we evaluate the models of career development (as they are set up) in the two uniformed services regimes: military and statutory (police, and penitentiary).

We try to identify the (i) hurdles to achieving successful career development in the different services, (ii) identify legacies that inhibit the adoption of more effective HRM tools, and (iii) evaluate the compatibility of the two regimes within the broader regulatory context of civil service. We approach our study from the institutionalist perspective and by combining methods of document analysis of regulation and interviews with servicemembers with differing professional experiences, we attempt to discern the differing levels of institutionalization of career development in the two service regimes. The paper consists of three sections: (i) the presentation of our theoretical construct, (ii) the presentations of study results and (iii) a discussion regarding the HRM implication of our findings.

\section{Adopting the institutionalist perspective to comparing carreer development systems}

Our study utilized the (neo-) institutionalist paradigm. Although it encompases a variety of theories [10] and does not have a common ontological "core" [6]. However, a key institutionalist assumption is that structures and agents interact dynamically 
constructing one another. Management cannot endlessly manipulate employees, or to that matter enforce behavior through regulation, and both sides have goals, expectations and power. The interaction of various actors and stuctures may result in outcomes that all sides may find desirable to change. From this perspective in public management, therefor, the illuminating what exactly are the causes of certain outcomes may lead to finding common ground for change, which all actors can agree to support. Given the variety of institutionalist approaches, structuring them proves a serious challenge. Heiskala \& Husso [7], proposes classifying the different institutionalist theories as a range of structure v. agency explanations of causal mechanisms. At one extreme we find the deterministic idea of "biology is fate", otherwise the thoroughly constructivis discursive and habitual institutionalisms (see Table 1).

\section{Table 1. The range of institutional theories}

\begin{tabular}{|c|c|c|c|c|c|c|}
\hline & $\begin{array}{c}1 . \\
\text { Biology }\end{array}$ & $\begin{array}{c}2 . \\
\text { Rational } \\
\text { choice }\end{array}$ & $\begin{array}{c}3 . \\
\text { Regulative } \\
\text { institutio- } \\
\text { nalism } \\
\end{array}$ & $\begin{array}{c}4 . \\
\text { Normative } \\
\text { institution- } \\
\text { nalism } \\
\end{array}$ & $\begin{array}{c}5 . \\
\text { Discursive } \\
\text { institutionalism }\end{array}$ & $\begin{array}{c}6 . \\
\text { Habitual } \\
\text { institutio- } \\
\text { nalism } \\
\end{array}$ \\
\hline $\begin{array}{l}\text { Basis of } \\
\text { compliance }\end{array}$ & $\begin{array}{l}\text { Disposi- } \\
\text { tions based } \\
\text { on nature }\end{array}$ & Utility & Expedience & $\begin{array}{c}\text { Social } \\
\text { obligation }\end{array}$ & $\begin{array}{l}\text { Taken-for- } \\
\text { grantedness, } \\
\text { shared } \\
\text { understanding }\end{array}$ & $\begin{array}{c}\text { Shared } \\
\text { dispositions }\end{array}$ \\
\hline $\begin{array}{l}\text { Basis of } \\
\text { order }\end{array}$ & $\begin{array}{l}\text { Biological } \\
\text { determina- } \\
\text { tion }\end{array}$ & $\begin{array}{l}\text { Rational } \\
\text { choise }\end{array}$ & $\begin{array}{l}\text { Regulative } \\
\text { rules }\end{array}$ & $\begin{array}{l}\text { Binding } \\
\text { expecta- } \\
\text { tions }\end{array}$ & $\begin{array}{l}\text { Constitutive } \\
\text { schemas }\end{array}$ & $\begin{array}{c}\text { Taken-for- } \\
\text { granted } \\
\text { ways of } \\
\text { acting } \\
\end{array}$ \\
\hline Mechanisms & $\begin{array}{l}\text { Natural } \\
\text { selection }\end{array}$ & $\begin{array}{l}\text { Utility } \\
\text { maximiza- } \\
\text { tion }\end{array}$ & Coercive & Normative & Mimetic & Habitual \\
\hline Logic & Survival & Calculation & $\begin{array}{c}\text { Instrumen- } \\
\text { tality }\end{array}$ & $\begin{array}{c}\text { Appropria- } \\
\text { teness }\end{array}$ & Orthodoxy & Pragmatic \\
\hline Indicators & $\begin{array}{l}\text { Regularity } \\
\text { in nature }\end{array}$ & $\begin{array}{c}\text { Cross- } \\
\text { cultural } \\
\text { prevailence }\end{array}$ & $\begin{array}{c}\text { Rules, } \\
\text { laws, } \\
\text { sanctions } \\
\end{array}$ & $\begin{array}{l}\text { Proprieties, } \\
\text { obligations }\end{array}$ & $\begin{array}{l}\text { Common beliefs, } \\
\text { shared knowledge }\end{array}$ & Habits \\
\hline $\begin{array}{l}\text { Basis of } \\
\text { legitimation }\end{array}$ & $\begin{array}{l}\text { Laws of } \\
\text { nature }\end{array}$ & $\begin{array}{l}\text { "Invisible } \\
\text { hand" }\end{array}$ & $\begin{array}{c}\text { Legally } \\
\text { sanctioned }\end{array}$ & $\begin{array}{l}\text { Morally } \\
\text { governed }\end{array}$ & $\begin{array}{l}\text { Comprehen- } \\
\text { sibleness, } \\
\text { recognizability, } \\
\text { culturally } \\
\text { supported }\end{array}$ & $\begin{array}{c}\text { Fluency of } \\
\text { action }\end{array}$ \\
\hline
\end{tabular}

Source: [7].

Our study was limited to the regulative and normative institutions. The mechods available to us within the scopes of the study were: (i) document analysis and (ii) interviews with servicemembers. From the point of view of other institutionalism we did not expect to find significant differences between the service regimes. Furthermore, to be able to look into discursive and habitual aspects of career development we need a good understanding between "neighbours" in the Heiskala \& Husso's range. Based on the our findings, however, we believe there is significant added value to achieved by conducting follow-up studies which would expand the 
range of methods and capture a greater section of the range of institutional theories.

We interviewed 16 servicemembers. The interviews were s-structured. The interviewers had a guideline, which required asking to elaborate the servicemembers on the following topics: (i) the conception of career development, (ii) the role of their service in assisting career development, (iii) exposure of servicemembers to managerial assistance with regard to career development. From the career development theory perspective our interviews also aimed at differentiating the (i) personal and (ii) organizational career models [14], and the elements of career development as described by Adekola [1]: (i) career planning; (ii) career management; (iii) motivation; (iv) job satisfaction.

However, what our regulatory analysis of these dimensions showed, that there is little reflection on the part of regulators along the lines of the types and elements of career development models and elements outlined in literature, the regulation describes the general legal grounds for hiring, remunerating and awarding, and discharging servicemembers. This, of course reflects elements of Adekola's [1] definition of career development, as being organized, formalized and planned to manage the balance between personal and organizational needs. Yet, the guidelines, which would allow HR managers to personalize career development, are nor formalized. With this in mind, we believe that claiming, especially in the case of statutory service, that there are models for career development in place is open for further contestation. The difference between the military and statutory services with respect to career development is incremental, rather than categorical.

One other niuance that we found to be important to address in our interviews was the fact that the growth of attention to career development in management is attributed to the globalization-induced changes in the labor market [4]. Increased competition created the more opportunities for mobility of employees, while on the other hand this also translated in greater insecurity for employees, as pressures to automate business processes and pursue savings grew [12]. Public sector is not immuned to those forces either [13]. Uniformed services being regimes of labor relations, which are highly specialized, and to some extent isolated from the regular labor market forces may not be affected by similar challenges.

Based on these asumptions our study identified two key dimensions to career development in the uniformed services: (i) what is the degree of discretion in the uniformed services to develop and utilized career development tools, and (ii) how does this correspond to the expectations of servicemembers?

\section{Key results: discretion v. regulation and chaos v. corruption}

In Lithuania career development as a management service to military and statutory servicemembers is not explicitily outlined. However, internal hiring, consultations, etc. available. Yet the resources and attention of senior management differ significantly. Paradoxically, our assumptions at the outset of the study that high regulation automatically corresponds to low discretion and vice-versa were disproved. In fact more types of career development can be discerned (see Table 2). This raises a 
question whether in developing career development mechanisms in uniformed service focus should be placed on greater regulation, or professional empowerment of of HR managers. Our study in this case is limited as we only compared the military service to statutory services, which clearly showed that the model of the military is preferred by servicemembers, and corresponds to the understanding of what would constitute a "good" carreer development model among statutory servicemembers. However, we also recognize profound differences among the organizational cultures of the military and statutory services, and believe a measure of standard setting by means of regulating is an important precaution before allowing for greater discretion in HR management in the statutory services.

\section{Table 2. Types of career development models in uniformed services in Lithuania}

\begin{tabular}{|c|c|c|}
\hline & Highly regulated & Moderately regulated \\
\hline $\begin{array}{c}\text { High level of discretion of } \mathbf{H R} \\
\text { managers }\end{array}$ & Military service regime \\
\hline $\begin{array}{c}\text { Low level of discretion of } \mathbf{H R} \\
\text { managers }\end{array}$ & Statutory service regime \\
\hline
\end{tabular}

Source: created by authors.

Constitutionally (Article 141), in Lithuania the statutory service regime is awarded to structures that perform functions that in effect constitute para-military activities. The kye legal distinction between a statutory servant and a civil servant is the right to issue orders to persons not directly subordinanted to the servant. In practice, however, institutions that have a uniformed element: police, penitertiary service, border guard service, etc. sometimes employ many of their servants in a uniformed capacity, despite the actual servants not performing functions that require a right to issue orders to persons not directly subordinated. To a large degree, the assignment of a statutory or civil servant is up to the discretion of respective institutions, and mobility between the two regimes is limited even within the same institution.

Both the military and statutory services are seen as being of fundamental importance to national security and these services are recognized as being potentially hazardous. Therefore, social security provisions are regulated separately in the respective statutes in these regimes. One important finding of our analysis was that the statutory service members have in many instances cited the lack of a sense of social security despite the special status, and this was manifestly not the case with military service. One important element in the accounts was a low level of income; lower that what they would expect, given current conditions in the labor market. Although the military is in a similar predicament, servicemembers of the military did not cite a sense of insecurity. Conversely, military servicemembers reported that they understood their career perspective, and that there was an element of planning from both their own perspective, and on behalf of the military. This was manifestly not the case with statutory service. Servicemembers in the statutory regime felt stuck in their current position and did not feel they understood the causal mechanisms of being 
promoted. Although in the military, some differentiation were seen to have potential to reduce in-service competition for promotion. In other respects members of both service regimes conceptualized the idea of career similarly, generaly having two traits: (i) professional skills development and (ii) hierarchical promotion. Remuneration, as such was not seen as a separate issue from promotion, the egalitarian idea of rank over competency is universaly accepted.

Despite the findings that the military service was reported to fair significantly better, this does not mean that shortcommings were not identified. In both services the importance in career development of direct superiors was seen to create arbitrariness, which did not correspond to ideas of meritocracy. However, the annouyance among military servicemembers with the lack of meritocracy in promotion was greater. The statutory servicemembers also recognized the lack of meritocracy, however they saw this lack as part of the organizational culture, which is impossible to change.

Military servicemembers also demonstrated issues that demonstrate a higher order of career development compared to statutory services. In case of the military one important distinction was the perception that training is key to career advancement, and servicemembers reported severe competition to gain access to training, which is limited to their liking.

On the other hand, no such issues were reported by statutory servicemembers, rather corruption was cited in various instances as an important negative element of organizational culture, which negate any attempts at individually pursuing career development. In summary (see Table 3), we see that in neither of the service regimes career development is pro-adtively managed, yet the way career advancement is conducted, greater opportunities for cross-unit mobility, and transparency of the process of career in the military set a high bar for the HR management in statutory services.

Table 3. Key categories of differences in career development between military and statutory services

\begin{tabular}{|l|l|l|}
\hline & \multicolumn{1}{|c|}{ Military } & \multicolumn{1}{c|}{ Statutory } \\
\hline Carreer planning & $\begin{array}{l}\text { Mostly up to the individual, contingent on } \\
\text { superiors }\end{array}$ & Arbitrary, corrupt \\
\hline Career managing & Chaotic & Non existant \\
\hline Motivation & High motivation, especialy to engage in training & Low, clear elements of dissingagement \\
\hline Job satisfaction & High & Low \\
\hline
\end{tabular}

Source: created by authors.

\section{Implications for HRM development}

Uniformed services are globally a bastion of the career public service model. In it, career is primarily charackterized by linearity and continuous service in the same organization, which defines stages of career through hierarchical ranking, and where ranks correspond to remuneration [5]. This is true in the case of Lithuania: strict hierarchies and discipline, focus on loyalty are key features of process organization in 
these services. Therefore, prior experience of independence in 1920s and 30s could not have been guide for the adoption of modern HRM practices. Soviet-era legacy, furthermore, was not based on rule of law [9]. Uniformed servicemembers were hostages to the same institutional logic and social behaviors, that the rest of society was - servicemembers could not affect their career development in a predictable and causal manner. Jugling seniority with meritocracy in career advancement is an ever present HRM challenge in the military services. Career development tools offer a possibility to falsify this dichotomy. The shift towards career development models that offer a measure of predictable and causality to promotion can be beneficial to uniformed services in ways similar to other types of public employment. Career development tools need not be seen as positions public service model elements that are hart to reconcile with the profound career model principles of uniformed service. Rather, career development offers flexibility for organizations to react to changes in policy, operational environments and labor markets at a faster pace without giving the impression among servicemembers of unfair treatment - a common criticism to the positions system.

Some research into Lithuanian military [8] demonstrated that essentially the career paths are defined by the organization, and servicemembers have little impact in shaping these paths. Our study also shows that encouraging the HR managers to offer options would be very welcomed by servicemembers of both uniformed services regimes, and is one innovation that is likely to encourage engagement, high morale, and rapid improvement of skills among servicemembers.

We believe that implementing pilot HRM processes, which would decentralize some of the career planning and decisions to the level of individual servicemembers may yield positive results for the military. Jonuškienè [8] identified lack of foresight of possibilities for training and necessity to gain higher ranks to perform certain tasks. Therefore, training is often not actualized, as it is not aligned to promotions. Our study has showed that this remains the case, and as a result - this the area where we see potential for initial pilot projects. On the other hand, statutory services conversely would do better if they adopted the role of follower, adopting best practices from the military by introducing them in regulation.

An important aspect of career in the uniformed services is that uniformed personnel serves side by side with civil servants. Military, police, and penitentiary organizations make extensive use of the civil service regime. The civil service is in many instances seen as more modern, and more flexible [2]. And the fact that career development in the civil service is not co-ordinated to the uniformed services means that organizations cannot make good use of horizontal employee mobility across this divide.

What we find in both services regimes is that career development has a measure of arbitratrity. Career managers and individual career plans in the military as mostly seen as formalities. The interviewees do not see how their personal career aligns with the fate of their organizations. Rather, a hierarchical relation between the organization and servicemembers comes across: the organization is seen as a structure that should 
provide more options for personal development and career, but servicemembers do not see how that would enhance the performance of the organization. This one-way conception of career, we believe, is a result that at the regulatory level, that of statutes there is no official conception of mutually beneficial career management.

On one of the questions, we asked the servicemembers, was to comment on what hurdles they find to be most important for their career development (see Table 4). Themes of lack of training, which has direct implication for advancement, was the only theme that overlapped. Manifestly, the military had higher demands towards their management: to find ways to make sure that horizontal mobility (rotation) would take to account career perspective of servicemembers, training would be better tailored to the needs of lines of service or careers, better identify the initiative of servicemembers and reward them with career opportunities. All these expectations can be addressed with a career development system. We see that inside the military there is an understanding of different elements of career development and we believe it would be well received by servicemembers. On the other hand, the statutory servicemembers identified more basic clarity-of-rules type challenges, such as inadequately inflated requirements for attaining higher ranks, low salaries, and inadequates social protection. These expectations indicate that the culture of statutory service organizations lags far behind that of the military. Nonetheles, this reinforces the need or a career development system, but in a more formalized, and politically supervised manner than in the military. One expetion from the stark differences of the two regimes we looked in was the reported attractiveness of professional experience in statutory services to the labor market, while military skills were not seen as highly regarded. Statutory servicemembers believe they find employment in legal and security services in the long term, and therefore see their service period as an investment. The military servicemembers saw fewer alternatives. Yet, this was not reported as a big problem, as in-service job and social security, as well as post-service social security in addition to the possibility of becoming proficient in English, and experiencing NATO alies' practices and cultures were highly regarded.

\section{Table 4. Hurdles to personal career development as reported by interviewees}

\begin{tabular}{|c|c|}
\hline Statutory service & Military service \\
\hline - $\quad$ To high advancement hurdles & - $\quad$ Skills aren't rewarded with higher ranks \\
\hline - $\quad$ Absense of meritocracy & - Training is not always beneficial or directly related to \\
\hline - Remuneration does not correlates with & professional challenges \\
\hline personal effort and results & - Horizontal mobility \\
\hline - Few training opportunities & opportunities, personal wishes aren't taken to account \\
\hline - Absense of culture of co-operation & _ Few training opportunities \\
\hline _ Low salaries & - Absense of career options as a result of showing \\
\hline - Inadequate social guarantees & initiative (as opposed to following preset rules) \\
\hline
\end{tabular}

Source: created by authors.

Overall, the exposure of the military services to the international context of similar organizations and the fact that soviet legacy does not impact the organizational culture suggests that the military fairs better in the labor market 
context. However, the current regulation allows ample space to setup a career development model, which would be better focuse on co-ordinating the achievements of both the military and its servicemembers. At the moment the personal career development broadly matches the expectations of military servicemembers, nonetheless its ad hoc nature means that them benefits to the military are limited, and a measure of arbitratiry remains an issue.

In statutory services the attractiveness of employment seems to consist of two parts: better future prospects in the labor market, and lack of alternatives for the moment. By no measure can it be considered that career development in statutory service represents good practice. Yet, the hierarchical culture of the statutory service means that policy-makers to a much greater degree than in the military should oversee the mechanism of adopting a career development model. Also, the statutory services have an opportunity to transpose many of the practices from the military. The international co-operation of the military far exeeds international co-operation of other services. The military can, and we believe should, become a gateway for other uniformed services to adopt best HRM practices. The reason for this is one important observation that we can made during the interviews: attitudes to career and its end goals are remarkably similar between servicemembers of the two services regimes, therefore at the normative level we can assume that HRM measures that satisfy military servicemembers, would be seen positively by statutory servicemembers.

\section{Conclusion}

1. In Lithuania there are two uniformed services regimens: military and stutory. Statutory regime has multiple statutes, which are passed by the parliament and have a status of law, spanning many ministerial areas of responcibility. Regulation on public employment in Lithuania is not integrated, and no attempts are being made to that end. Rather the varying statutes, law on civil service, and regular employment under the code of labor are used by public organizations with a high degree of discretion.

2. The two uniformed services regimes we looked at - military and statutory (police and penitentiary) suggests that there are many significant differences in how career development is managed. In both cases career development is not a concept or a set of HRM instruments that is recognized in regulation. However, the military applies many of the instruments, which in literature are defined as career management. In the case of the statutory service regime this was not found to be the case.

3. Personal advancement and career development in the military is seen generaly favorably by sservicemembers. Both in the sense of HRM processes benefitting the military, and the organization. Statutory servicemembers conversley see personal advancement as an arbitrary process, which does not clearly relate to the goals of their organizations. The possibility for discretion in applying HRM tools with regard to establishing career development in underutilized by statutory organizations, and this has a negative effect on the attitudes of servicemembers to their personal 
career planning, loyalty, and engagement.

4. The military may banefit at expading career development tools, and applying them more systematically, especially with regard to aligning expectations for career of individual servicemembers, their training, and correlation of training with ranks, so that training is effective and utilized in practice. Statutory services may benefit in adopting best practices from the military. However, due to considerable institutional innertia, which can be traced back to 1990, a regulatory intervention on behalf of the executive, or legislative branches of the government would be necessary.

5. At the normative level, attitudes to career development of both military and stutory servicemembers are similar, so is the HR regulation. The key differences between the two regimes bocomes apparent when questions on whether management career development is applied appropriately, that differences occur. These findings lead us to conclude that servicemembers would welcome the adoption of career development models. In the case of military this, we believe, can be achieved within the institution, in cases of satutory services ministerial oversight may be necessary.

\section{References}

1. Adekola, B. Career Planning and Career Management as Correlates for Career Development and Job Satisfaction: A Case Study of Nigerian Bank Employees. Australian Journal of Business and Management Research, 2011, Vol. 1, No 2, p. 100112.

2. Bagdonienè, A. Career System of Career Civil Servant and Professional Military Service Soldier: A Comparative Analysis. Vilnius: Mykolas Romeris University, 2012.

3. Bileišis, M., Kovač, P. Conclusion: Main Themes of Public Administration Reforms in the Eastern EU Member States. In: P. Kovač and M. Bileišis (eds.). Public Administration Reforms in Eastern European Union Member States: Post-accession Convergence and Divergence. Vilnius; Ljubljana: Baltic Printing House, 2017, p. 471 491.

4. Cuterela, S. Globalization: Definition, Processes and Concepts. Romanian Statistical Review - Trim Supplement (IV), 2012, Vol. 60, No 4, p. 137-146.

5. Gruževskis, B. et al. Pareigūnu ir kariu antroji karjera. Vilnius: Lietuvos kariuomenès Karo kartografijos centras, 2014.

6. Hall, P. A., Taylor, R. C. Political Science and the Three New Institutionalisms. Political studies, 1996, Vol. 44, No 5, p. 936-957.

7. Heiskala, R., Husso, M. The Power of Institutions in Shaping Agency. The Case of Gender. Proceedings of the Annual American Sociological Association Meeting, USA, San Francisco, August 08, 2009.

8. Jonuškienè, I. The Features of Human Resources Management in the Army of the Republic of Lithuania. Šiauliai: Šiauliai University, 2009.

9. Laurinavičius, A., Jovaišienè, R. Customs and Career Problems. Jurisprudence, 2003, Vol. 49, No 41, p. 32-46.

10. March, J. G., Olsen, J. P. Elaborating the „New Institutionalism“. In: The Oxford 
Handbook of Political Institutions. Oxford: Oxford University Press, 2006, p. 3-20.

11. Smalskys, V. et al. Public Sector Reforms in Lithuania Since 1990. In: P. Kovač and M. Bileišis (eds.). Public Administration Reforms in Eastern European Union Member States: Post-accession Convergence and Divergence. Vilnius; Ljubljana: Baltic Printing House, 2017, p. 50-89.

12. Tlaiss, H. A. Between the Traditional and the Contemporary: Careers of Women Managers from a Developing Middle Eastern Country Perspective. The International Journal of Human Resource Management, 2014, Vol. 25, No 20, p. 2858-2880.

13. Vinkenburg, C. J., Weber, T. (2012). Managerial Career Patterns: A Review of the Empirical Evidence. Journal of Vocational Behavior, 2012, Vol. 80, No 3, p. 592-607.

14. Wesarat, P. et al. (2014). A Review of Organizational and Individual Career Management: A Dual Perspective. International Journal of Human Resource Studies, 2014, Vol. 4, No 1, p. 101-113.

\section{Svajūnė Ungurytė-Ragauskienè, Mantas Bileišis}

\section{Karjeros vystymas profesinėje karo ir statutinëje tarnybose: atviros durys inovacijoms vesrus inertiška hierarchinė kultūra}

\section{Anotacija}

Straipsnyje pristatomas dviejų viešosios tarnybos režimų, profesinès karo ir statutinès, karjeros vystymo raiškos lyginamasis tyrimas. Tyrimas atliktas institucionalizmo teorinèje perspektyvoje gretinant reguliacinio ir normatyvinio institucionalizmo teorines jžvalgas. Tyrimo metu analizuoti profesinès karo tarnybos, policijos ir tarnybos kalejimų departamente statutai, kurie gretinti su pusiau struktūruotais pareigūnų, tarnaujančių profesinèje karo ir statutinèje tarnybose, interviu. Tyrimo rezultatai parodè, kad statutų struktūra yra panaši ir tiesiogiai neįvardina karjeros vystymo kaip žmogiškujų išteklių veiklos elementų. Tarnybos sąlygos, kuriose įtraukiami kai kurie žmogiškujjų išteklių valdymo elementai, kurie priskiriami karjeros valdymui mokslinèje literatūroje, statute struktūra, vis tik yra orientuota tik ị tris etapus: prièmimo i tarnybą, tarnybos, atleidimo iš tarnybos. Interviu parodè, kad toks reglamentavimas palieka daug erdvès administracinei diskrecijai. Administracinè diskrecija leidžia diegti žmogiškųjų išteklių valdymo inovacijas, tačiau tuo pačiu tiek karo tarnybos, tiek statutinejje tarnyboje respondentai pripažino, kad karjeros vystymas labai priklauso nuo tiesioginių vadų požiūrio. Tačiau profesinejje karo tarnyboje įdiegta daugiau karjeros vystymo elementų, jie veikia nuosekliau, organizacinè karo tarnybos kultūra skatina konkurenciją dèl karjeros galimybių, o karininkai mano, kad karjeros vystymas iš esmès atitinka jų lūkesčius dèl sąžiningumo ir asmeninių perspektyvų tarnyboje. Visais šiais požymiais nepasižymi statutinè tarnyba, kurioje neatitikimas tarp pareigūnų lūkesčių ir to, kaip vertinamas karjeros vystymas jų tarnybose nesutampa. Karo tarnybą nuo statutinès Lietuvoje skiria du svarbūs požymiai: intensyvus bendradarbiavimas su užsienio valstybių karo tarnybomis NATO kontekste ir tai, kad ši tarnyba sukurta nepriklausomoje Lietuvoje, tuo tarpu kai statutinė tarnyba didele dalimi paveldèjo personalą ir organizacinę kultūrą iš sovietmečio periodo ir jos kaita yra inkrementinè. Viešajam sektoriui nepalankioje Lietuvos darbo rinkoje matome daug potencialo kurti nuoseklias karjeros vystymo tiek kariuomenèje, tiek statutinèje tarnyboje, tačiau tuo pačiu statutinès tarnybos institucijos jau dabar galètų perimti itin daug gerosios profesinès karo tarnybos praktikos elementų. 
Svajūnè Ungurytè-Ragauskiene is a Master of Public Administration, researcher of the Public Mangement Innovation Laboratory at Mykolas Romeris University. E-mail.: svajune.unguryte@gmail.com.

Mantas Bileišis is an Assoc. Prof. of the Institute of Public Administration, and head of the Public Management Innovation Laboratory at Mykolas Romeris University. E-mail.: mantas.bileisis@mruni.eu.

Svajūnè Ungurytè-Ragauskienè yra Mykolo Riomerio universiteto, Viešojo administravimo instituto magistrè, Viešojo valdymo inovacijų laboratorijos tyrèja. E.paštas: svajune.unguryte@gmail.com.

Mantas Bileišis yra Mykolo Riomerio universiteto, Viešojo administravimo instituto docentas, Viešojo valdymo inovacijų laboratorijos vadovas.

E.paštas:mantas.bileisis@mruni.eu.

Straipsnis įteiktas redakcijai 2017 m. rugpjūčio mèn.; recenzuotas; parengtas spaudai 2017 m. spalio mèn. 